\title{
Cryopreservation of tambaqui semen using a dry shipper and a programmed freezing machine
}

\section{Criopreservação do sêmen de tambaqui utilizando dry shipper e máquina de congelação programada}

\author{
Mayara Setúbal Oliveira ${ }^{1}$; Priscila Silva de Almeida-Monteiro ${ }^{1}$; \\ Larissa Teixeira Nunes ${ }^{1}$; Francisco Renan Aragão Linhares ${ }^{1}$; João Paulo Silva \\ Pinheiro $^{2}$; Romulo Roberto Ribeiro Pinheiro ${ }^{3}$; Filipe Oliveira Ferreira ${ }^{4}$; \\ Claudio Cabral Campello ${ }^{5}$; Carminda Sandra Brito Salmito-Vanderley ${ }^{6^{*}}$
}

\begin{abstract}
Tambaqui (Colossoma macropomum) is a native freshwater fish that is of great importance for Brazilian aquaculture. Because of this importance, several techniques have been developed to improve the reproduction of this species in captivity. One of these techniques is the cryopreservation of sperm. In an effort to increase the efficiency of cryopreservation protocols, researchers have tried to determine suitable diluting solutions and freezing methods, which will provide a better post-thaw sperm quality. Thus, this study aimed to evaluate the efficiency of different diluents and freezing methods for the cryopreservation of tambaqui (C. macropomum) sperm. Samples of fresh semen were diluted in different treatments (Glucose 5\% + 10\% Dimethyl sulfoxide - DMSO, Glucose 5\% + 10\% Methyl glycol-MG, BTS + 10\% DMSO and BTS $+10 \% \mathrm{MG}$ ) at a 1:9 dilution rate and frozen in a programmed freezing machine and a dry shipper. The semen samples were thawed and evaluated for vitality, sperm morphology and kinetics. Cryopreserved semen with DMSO and using the programmed freezing machine provided a greater percentage of motile sperm $(15.44 \pm 1.04 \%)$ after thawing compared to the dry shipper $(3.99 \pm 0.55 \%)$, regardless of the diluent. Additionally, DMSO showed better sperm velocities than MG regardless of the freezing method and the extender employed. A higher percentage of living spermatozoa was observed when glucose $(37.28 \pm 1.32 \%)$ (regardless of the freezing method and cryoprotectant) and DMSO $(37.98 \pm 1.25 \%)$ was used in the programmed freezing machine. For morphology, a greater amount of normal spermatozoa $(46.10 \pm 1.82 \%)$ was observed when the semen was cryopreserved using a freezing machine programmed with DMSO as the cryoprotectant and Glucose or BTS $(38.16 \pm 1.9 \%$ and $39.26 \pm$ $1.87 \%$, respectively) as extenders. Therefore, we suggest the use of the DMSO (10\%) cryoprotectant in association with the Glucose (5\%) extended in the programmed freezing machine for cryopreservation of C. macropomum semen.
\end{abstract}

Key words: Colossoma macropomum. Conservation methods. Extenders. Sperm class analyzer. Teleost.

1 Discentes do Programa de Pós-Graduação em Ciências Veterinárias, Universidade Estadual do Ceará, UECE, Fortaleza, CE, Brasil. E-mail: maysetubal31@gmail.com; priscilla_vs@hotmail.com; larissatn.br@hotmail.com; renan.aragao@hotmail.com

2 M.e em Ciências Veterinárias pelo Programa de Pós-Graduação em Ciências Veterinárias, UECE, Fortaleza, CE, Brasil. E-mail: joaopaulospinheiro@yahoo.com.br

3 Discente do Curso de Graduação em Ciências Biológicas, UECE, Fortaleza, CE, Brasil. E-mail: romuloroberto_bio@hotmail. com

4 Discente do Curso de Graduação em Medicina Veterinária, UECE, Fortaleza, CE, Brasil. E-mail: fpeferreira20@gmail.com

5 Prof. Dr., Faculdade de Veterinária, UECE, Fortaleza, CE, Brasil. E-mail: claudio.campello@uece.br

${ }^{6}$ Prof $^{\mathrm{a}}$ Dra ${ }^{\text {a }}$, Curso de Ciências Biológicas, UECE, Fortaleza, CE, Brasil. E-mail: sandra.salmito@uece.br

Author for correspondence 


\section{Resumo}

O tambaqui (Colossoma macropomum) é uma espécie nativa de peixe de água doce de grande importância para aquicultura brasileira. Devido a isso, diversas técnicas têm sido desenvolvidas para aperfeiçoar a reprodução desta espécie em cativeiro, dentre elas a criopreservação de sêmen de peixe. Como uma forma de melhorar os protocolos de criopreservação, tem-se buscado utilizar soluções diluidoras e métodos de congelação adequados, proporcionando uma boa qualidade seminal pós-descongelação. Dessa forma, este estudo objetivou avaliar a eficiência de diferentes diluidores e métodos de congelação na criopreservação do sêmen de tambaqui (C. macropomum). As amostras de sêmen fresco foram diluídas em diferentes tratamentos (Glicose 5\% + 10\% Dimetilsufóxido - DMSO; Glicose 5\% + 10\% Metil glicol - MG; Beltsville Thawing Solution - BTS + 10\% DMSO e BTS + 10\% MG) na proporção 1:9 e congeladas em máquina de congelação programada e em Dry shipper. As amostras seminais foram descongeladas e avaliadas para vitalidade, morfologia e cinética espermáticas. O sêmen criopreservado com DMSO utilizando a máquina de congelação programada proporcionou maiores percentuais de espermatozoides móveis $(15,44 \pm 1,04 \%)$ após a descongelação em relação ao Dry shipper $(3,99 \pm$ $0,55 \%$ ), independente do diluente utilizado. Além disso, DMSO proporcionou as melhores velocidades espermáticas em relação ao MG, independente do método de congelação e diluente empregado. Um maior percentual de espermatozoides vivos foi observado quando se utilizou Glicose $(37,28 \pm 1,32 \%)$ como diluente (independente do método e crioprotetor), e DMSO $(37,98 \pm 1,25 \%)$ em máquina de congelação programada. Para a morfologia espermática, uma maior quantidade de espermatozoides normais $(46,10 \pm 1,82 \%)$ foi observada quando o sêmen foi criopreservado usando a máquina de congelação programada com o DMSO, para os crioprotetores, Glicose e BTS $(38,16 \pm 1,9 \% ; 39,26 \pm$ $1,87 \%$, respectivamente), para os diluentes. Portanto, sugere-se a utilização do crioprotetor DMSO 10\% associado ao diluente Glicose 5\% em Máquina de Congelação Programada, para a criopreservação do sêmen de C. macropomum.

Palavras-chave: Colossoma macropomum. Diluidores. Métodos de conservação. Sperm class analyzer. Teleósteos.

\section{Introduction}

Tambaqui (Colossoma macropomum, Cuvier 1818), which belong to the Characidae family in the order Characiformes, are a Brazilian species of migratory fish from the Amazon River basin (GOULDING; CARVALHO, 1982). Because of its rusticity, texture and flavor of the meat and the good performance in captivity, its cultivation has been growing rapidly; among the native species of freshwater fish, it is the most cultivated in Brazilian aquaculture (BRASIL, 2011).

The high demand of tambaqui has caused the decline of natural populations, and the global expansion of aquaculture production has stimulated interest in the development of biotechnology for the reproduction of fish (KOPEIKA et al., 2007). Thus, aquaculture appears to be a tool to address fish production (HUNTER; ROBERTS, 2000), and among the technologies used in this area, semen cryopreservation stands out as a good alternative for improving the breeding of captive fish (VIVEIROS; GODINHO, 2009). This biotechnology assists in the genetic improvement of cultured stocks, provides a continuous supply of good quality semen (IRAWAN et al., 2010), and enables and optimizes the semen transport over long distances, which ensures exchanges between various research institutions and fish farming stations (CARNEIRO, 2007).

However, for the success of the technique, it is necessary to develop suitable cryopreservation protocols that are standardized for each species (CARNEIRO et al., 2012). Therefore, it is necessary to define the best diluting solution, which includes a diluent and a cryoprotectant, that is responsible for maintaining the semen quality after the thawing and freezing method has been employed.

When an interaction occurs between the diluting solution and the freezing method, the sperm cells may be damaged during the cryopreservation 
process. Thus, it is necessary to evaluate the postthaw sperm quality by analyzing some parameters that can negatively influence the fertilization rate including motility, morphology and sperm vitality (RURANGWA et al., 2004; VIVEIROS et al., 2011).

Among the diluents that have been successfully tested on several species, characiform, glucose and BTS (Beltsville Thawing Solution) have provided good motility rates when combined with dimethyl sulfoxide cryoprotectant (DMSO) or Methyl glycol (MG) as freezing mediums (VIVEIROS; GODINHO, 2009).

The freezing equipment frequently used for semen of native Brazilian fish includes dry shippers and thermal polystyrene boxes (VIVEIROS; GODINHO, 2009). Another method that has been employed is the use of a Programmed Freezing Machine (PFM), which aims to reduce the number of variables that interfere with the cryopreservation process, allowing for a gradual decrease and a controlled and homogeneous temperature.

However, little information is available regarding the use of programmed freezing equipment associated with the above extenders for tambaqui semen. Therefore, studies are required for the use of freezing machines for cryopreservation in the sperm of this species, which contributes to the technological advancement of its production in captivity.

Given the above information, this study aimed to evaluate the efficiency of different thinners and freezing equipment in the cryopreservation of tambaqui (C. macropomum) and examination of the effects on the kinetics, morphology and sperm vitality.

\section{Materials and Methods}

Animal handling, collection and evaluation of semen

All of the procedures in this study were approved by the Ethics Committee for the Use of Animals of the State University of Ceará (4565668/2014). The experiment was conducted during the month of January in the Applied Biotechnology Center for Aquaculture - Cebiaqua (344'25.0”' S, 38³4'29.1" W), the Federal University of Ceará (UFC) and the Laboratory of Biotechnology Fish Reproduction - LBRP (347’36.2” S, 38³3’30.1” W), State University of Ceará (UECE) in Fortaleza, Ceará, Brazil.

The tambaquis were kept in a masonry tank of approximately $800 \mathrm{~m}^{3}$ (water temperature 27 $\pm 0.7{ }^{\circ} \mathrm{C}$ ), at a density of $0.045 \mathrm{~m}^{3}$ fish, and fed an extruded diet containing $32 \%$ crude protein (commercial feed: $3 \%$ body weight) twice daily. A total of 30 adult males were selected according to the following characteristic: a hyperemic urogenital papilla and released a detectable amount of semen under mild abdominal pressure.

The animals were weighed $(4.10 \pm 0.44 \mathrm{~kg})$, measured $(55.63 \pm 2.33 \mathrm{~cm})$ and then induced to spermiation via intracelomic with a single dose of carp pituitary extract (CPE; $2.5 \mathrm{mg} \mathrm{kg}^{-1}$ of the body weight) according to Leite et al. (2013).

After 14 hours, the animals were sedated with a clove oil-based solution (Eugenol; União Vegetal Suplementos Nutricionais Ltda) at a ratio of 1:10:10000 (eugenol: absolute ethanol: water) until a loss of balance was evident. Then, the eyes were wrapped in a damp cloth and the urogenital papilla was cleaned and dried with a paper towel to avoid the prior activation of sperm on contact with the water, feces or urine of the animal.

The semen was collected using a slight abdominal pressure that was performed from head to tail to obtain the release of semen in graduated tubes of polyethylene. The tubes were kept in an insulated box with ice at approximately $4{ }^{\circ} \mathrm{C}$ until they were analyzed and processed. Then, the samples were transported to the LBRP, which was located $7 \mathrm{~km}$ from the site of collection, to cryopreserve the semen.

Before the cryopreservation, the motility of the fresh semen was analyzed using Computer Assisted 
Sperm Analysis (CASA) with the assistance of Sperm Class Analyzer software $\left(\mathrm{SCA}^{\circledR}\right.$, version 5.0, Microptics SL, Barcelona, Spain). For this process, $5 \mu \mathrm{L}$ of the semen was activated with 100 $\mu \mathrm{L}$ of a $\mathrm{NaCl}$ solution $(50 \mathrm{mM}-100 \mathrm{mOsm})$ and immediately investigated.

To evaluate the sperm kinetics, the following parameters were analyzed: percentage of mobile and static sperm, curvilinear velocity $\left(\mathrm{VCL}-\mathrm{s}^{-1} \mu \mathrm{M}\right)$, straight-line velocity (VSL $\left.-\mathrm{s}^{-1} \mu \mathrm{M}\right)$ and average path velocity (VAP $-\mu \mathrm{M} \mathrm{s}^{-1}$ ). They were assessed by at least by 1000 sperm per analysis.

The samples of fresh semen were evaluated for $\mathrm{pH}$ using test strips (Merck-Germany), and a total of $10 \mu \mathrm{L}$ of semen of each animal was deposited onto the strip. The volume and osmolality were measured using graduated tubes and a cooling digital osmometer PZL - 1000 (PZL, Brazil), respectively.

The evaluation of the sperm concentration (sperm $\mathrm{ml}^{-1}$ ) was performed following the methodology described by Paula et al. (2012), in which the semen was diluted in a $4 \%$ formal-citrate solution (1:1000) and the sperm count performed in a Neubauer chamber.

The sperm vitality was conducted by the eosinnigrosin staining method adapted (BLOM, 1950) using the ratio 1:10:10 (semen:eosin:nigrosin). After preparation of the slides (one slide per animal), 200 spermatozoa were analyzed using a light microscope $(400 \times)$. The vitality was calculated by a percentage, and dead spermatozoa were stained pink or red, and living spermatozoa were colorless.

The morphological analysis occurred after the semen from each animal was fixed in a $4 \%$ formalcitrate solution (1:10; semen:fixer) and stained with Rose Bengal (3:20; color:fixed semen). Two slides were prepared per animal, and 100 spermatozoa were evaluated per slide. The readings were taken with an optical microscope with a phase contrast aid (Nikon ${ }^{\circledR}$ H550S, ECLIPSE 50i, Japan) in the SCA program using the "Counter" module. The sperm were classified according to Miliorini et al. (2011).

\section{Cryopreservation of the semen}

Uncontaminated cryopreservation samples exhibiting motility $\geq 80 \%$ after activation $(n=29)$ were selected.

We used the following diluents: Beltsville Thawing Solution - BTS (Minitub, 318 mOsm) and commercial glucose (Fresenius Kabi Brazil Ltda, $309 \mathrm{mOsm})$. For the preparation of the BTS diluent (consisting of $79.90 \mathrm{~g}$ glucose, $12.71 \mathrm{~g}$ sodium citrate, $2.65 \mathrm{~g}$ EDTA, $2.65 \mathrm{~g}$ of sodium bicarbonate, $1.59 \mathrm{~g}$ of potassium chloride; and 0.50 $\mathrm{g}$ of gentamicin sulfate in $1.00 \mathrm{~L}$ of distilled water), a dilution of $50 \mathrm{~g}$ in $1000 \mathrm{~mL}$ of distilled water was performed according to the manufacturer's recommendation.

Semen from each animal was diluted at a ratio of 1:9 (semen:extender) on all treatments and loaded into $250 \mu \mathrm{L}$ straws, sealed at the ends with polyvinyl alcohol and placed in a freezer $\left(-10{ }^{\circ} \mathrm{C}\right)$ for 10 minutes to reach equilibrium. After this period, they were simultaneously frozen using two methods, where two straws of each treatment were utilized for the programmed freezing machine (PFM; Dominium K BIOCOM ${ }^{\circledR}$, Brazil), and two straws were placed in the dry shipper (DS; TaylorWharton, CP 300 model). A total of 464 straws (2 replicates per treatment $\times 4$ freezing medium $\times 2$ freezing methods $\times 29$ males) were cryopreserved.

For freezing in PFM, the straws were subjected to two freeze steps in the process: the temperature of the samples was reduced at a rate of $3{ }^{\circ} \mathrm{C} \mathrm{min}{ }^{-1}$ from $10{ }^{\circ} \mathrm{C}$ to $-12^{\circ} \mathrm{C}$ when the temperature reached the crystallization (step 1), and after one minute, the second step $\left(-3{ }^{\circ} \mathrm{C} \min ^{-1},-12{ }^{\circ} \mathrm{C}\right.$ to $\left.-60{ }^{\circ} \mathrm{C}\right)$ was started and followed by 30 minutes of stabilization. After the end of the PFM cycle, approximately 55 minutes, the straws were transferred to a liquid nitrogen container at $-196^{\circ} \mathrm{C}$.

Simultaneously, the straws of each treatment were taken to the DS where they remained for 15 minutes at a temperature of approximately -170 ${ }^{\circ} \mathrm{C}\left(-37{ }^{\circ} \mathrm{C} \mathrm{min}^{-1}\right)$ and then transferred to the liquid 
nitrogen container $-196^{\circ} \mathrm{C}$. All of the samples were stored for 10 days.

Thawing and evaluation of the kinetics, vitality, and sperm morphology

The samples were thawed in a water bath at 45 ${ }^{\circ} \mathrm{C}$ for $8 \mathrm{sec}$. An aliquot of each treatment was used for evaluation of the motility, kinetics, vitality and sperm morphology following the same methodology previously described for fresh semen.

\section{Statistical analysis}

The data were subjected to Shapiro-Wilk and Bartlett tests to verify the normal distribution of waste and homoscedasticity, respectively. After both of these requirements had been confirmed, the analysis of variance, considering a completely randomized design in a factorial arrangement $2 \times 2$ $\times 2$, represented by the effect of the cryoprotectant $(\mathrm{DMSO}+\mathrm{MG})$, the effect of the diluent (Glucose + BTS), the effect of the equipment (dry shipper + PFM), and the interactions between the main effects. When some of the main effects or interaction proved to be significant, the Student-NewmanKeuls (SNK) test was used to compare the means. The significance level was 5\% and the results were presented as the mean \pm the standard error.

\section{Results}

\section{Seminal characterization}

The results of the characterization of fresh semen of C. macropomum, and the weight and length of the animals are described in Table 1.

Table 1. Mean \pm standard deviation of the weight and parameters of fresh C. macropomum semen $(\mathrm{n}=30)$.

\begin{tabular}{lc}
\hline Parameter & Mean \pm S.D \\
\hline Body weight $(\mathrm{kg})$ & $4.10 \pm 0.44$ \\
Length $(\mathrm{cm})$ & $55.63 \pm 2.33$ \\
Volume $(\mathrm{mL})$ & $4.31 \pm 1.94$ \\
$\mathrm{pH}$ & $7.72 \pm 0.39$ \\
Osmolarity $\left(\mathrm{mOsm} \mathrm{kg}^{-1}\right)$ & $293.96 \pm 38.28$ \\
Concentration $\left(\mathrm{sptz} \mathrm{x} \mathrm{10}^{9} \mathrm{~mL}^{-1}\right)$ & $12.98 \pm 6.30$ \\
Total motility $(\%)$ & $97.8 \pm 1.8$ \\
VCL $\left(\mu \mathrm{m} \mathrm{s}^{-1}\right)$ & $109 \pm 19.22$ \\
VSL $\left(\mu \mathrm{m} \mathrm{s}^{-1}\right)$ & $43.7 \pm 10.28$ \\
VAP $\left(\mu \mathrm{m} \mathrm{s}^{-1}\right)$ & $84.3 \pm 14.76$ \\
Spermatozoa with normal morphology $(\%)$ & $91.6 \pm 3.60$ \\
Spermatozoa with intact membranes $(\%)$ & $95.9 \pm 4.13$ \\
\hline
\end{tabular}

\section{Sperm kinetic analysis}

For the parameter of total motility of the semen, there was no effect $(\mathrm{P}>0.05)$ of the diluents used in this study. However, there was an effect of the cryoprotectant and the interaction between the cryoprotectant and the freezing method used (P $<0.05$ ) as seen in Figure 1. 
Figure 1. Mean \pm standard error of the rate of the motility of post-thaw tambaqui semen using different cryoprotectants (Dimethyl sulfoxide - DMSO and methyl glycol - MG) and freezing methods. Capital letters indicate differences between equipment while using the same cryoprotectant. Lowercase letters indicate the difference between the cryoprotectant while using the same method of freezing $(\mathrm{P}<0.05)$.

DMSO $\square M G$

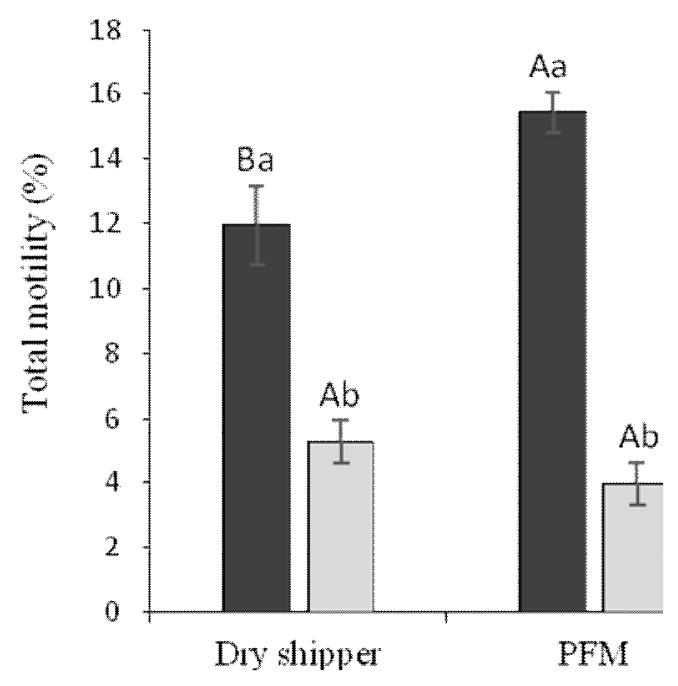

When comparing the cryoprotectants, semen cryopreserved as DMSO showed better motility rates $(\mathrm{P}<0.05)$ compared to the $\mathrm{MG}$, both in the DS (DMSO: $11.95 \pm 1.22 \%$; MG: $5.28 \pm 0.62 \%$ ) and in the PFM (DMSO: $15.44 \pm 1.04 \%$; MG: $3.99 \pm 0.55 \%$ ). For the semen cryopreserved with $\mathrm{MG}$, there was no difference between the values obtained $(\mathrm{P}>0.05)$ regardless of the equipment used. However, when using the freezing machine, DMSO showed higher values than the results with DS.

For the spermatic velocities, freezing of the semen using DMSO provided superior results $\left(\mathrm{VCL}=45.13 \pm 0.97 \mu \mathrm{m} \mathrm{s}^{-1}, \mathrm{VSL}=37.28 \pm 0.97\right.$ $\left.\mu \mathrm{m} \mathrm{s}^{-1} ; \mathrm{VAP}=37.28 \mu \mathrm{m} \mathrm{s}^{-1} \pm 1.05 ; \mathrm{P}<0.05\right)$ when compared to the cryopreserved samples with $\mathrm{MG}$ $\left(\mathrm{VCL}=39.42 \pm 1.13 \mu \mathrm{m} \mathrm{s}^{-1}, \mathrm{VSL}=14.29 \pm 0.93\right.$ $\left.\mu \mathrm{m} \mathrm{s}^{-1} ; \mathrm{VAP}=25.62 \pm 0.91 \mu \mathrm{m} \mathrm{s}^{-1}\right)$ regardless of the diluent and freezing method (Figure 2).

\section{Sperm vitality of analysis}

Regarding the sperm vitality, there was a significant effect of the diluents $(\mathrm{P}>0.05)$, and glucose had a higher rate of live sperm cells $(37.28 \pm$ $1.32 \%)$ compared to the BTS $(31.64 \pm 1.00 \%)$ with no influence of the cryoprotectants and the freezing method used for this parameter (Figure 3A).

There was no difference between the DMSO $(33.28 \pm 1.15 \%)$ and $\mathrm{MG}(36.77 \pm 1.39 \%)$ cryoprotectants when using DS ( $\mathrm{P}>0.05)$. However, when using the PFM, DMSO (37.98 $\pm 1.25 \%)$ in the semen cryopreservation provided a greater vitality rate compared to MG $(29.81 \pm 0.80 \%)$. Otherwise, the semen cryopreserved with MG using DS showed a higher percentage of live sperm $(36.77 \pm 1.39 \%)$ compared to the PFM $(29.81 \pm 0.80 \%, \mathrm{p}<0.05)$ as shown in Figure 3B. 
Figure 2. Mean \pm standard error of the kinetic parameters (Curvilinear velocity - VCL; straight-line velocity - VSL, and Average path velocity - VAP). Different lowercase letters indicate differences between cryoprotectants dimethyl sulfoxide (DMSO) and Methyl glycol (MG) within the same parameter $(\mathrm{P}<0.05)$.

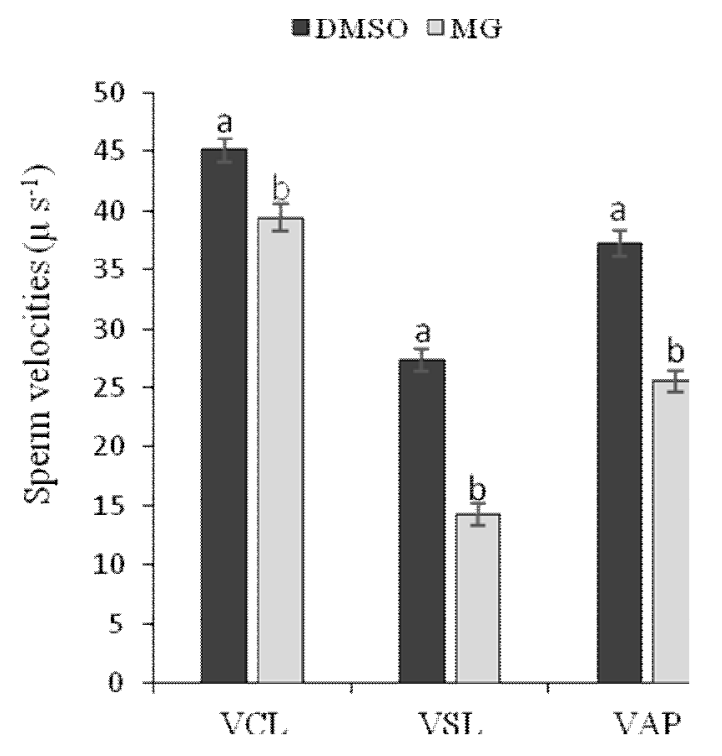

Figure 3. Mean \pm standard error of the percentage of sperm with an intact membrane (vitality) after thawing Colossoma macropomum semen: A) vitality rate of cryopreserved semen using the glucose diluents and Beltsville Thawing Solution (BTS) due to the significant effect the diluent; B) vitality rate of cryopreserved semen using the cryoprotectants dimethyl sulfoxide (DMSO) and Methyl glycol (MG) in the function of the interaction treatment $\times$ freezing method. Capital letters indicate differences between the equipment using the same cryoprotectant. Lowercase letters indicate the difference between the extenders and cryoprotectants using the same method of freezing $(\mathrm{P}<0.05)$.
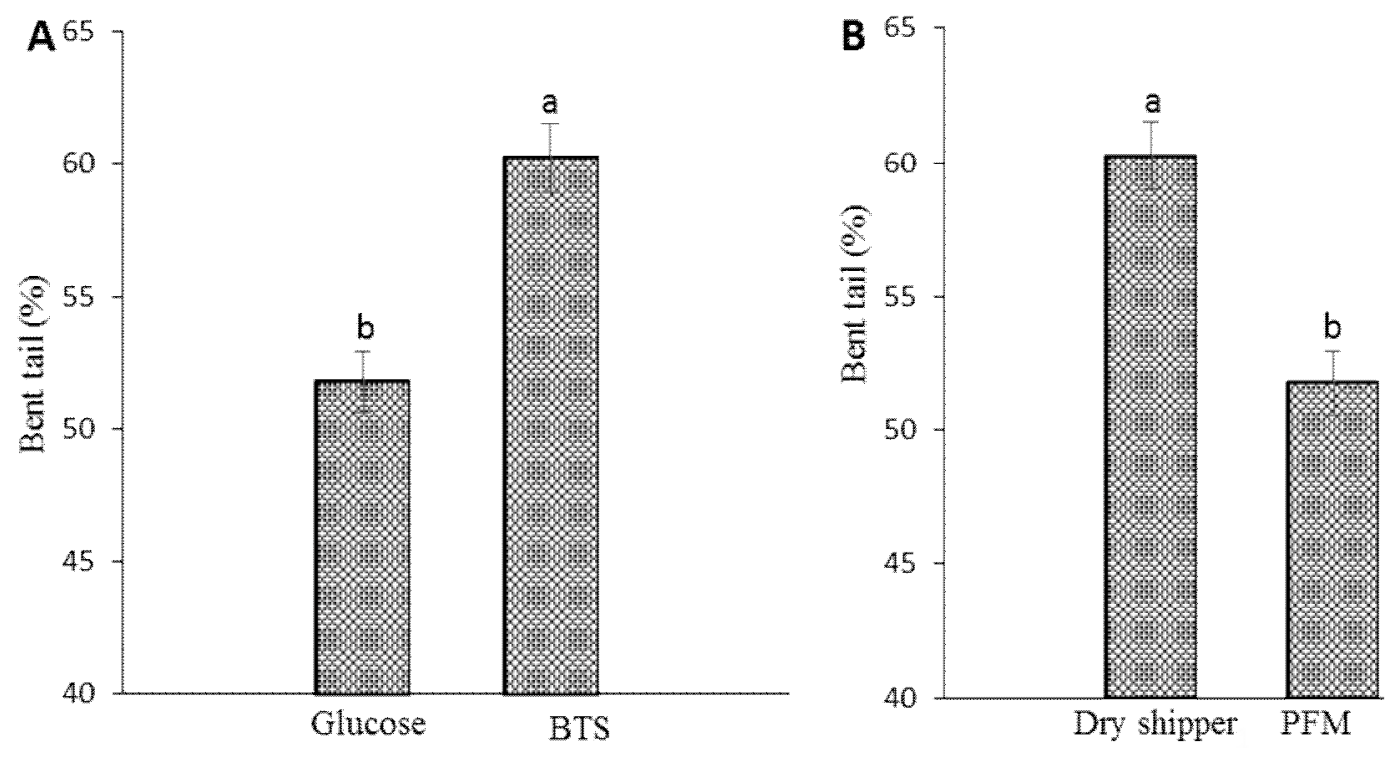
Analysis of the morphological spermatic

Concerning the morphologically normal sperm index, there was an effect of the interaction of the cryoprotectant $\times$ freezing equipment and the diluent $\times$ freezing equipment (Table 2 ).

The tambaqui semen cryopreserved with DMSO showed a higher percentage of normal spermatozoa $(\mathrm{P}<0.05)$ using PFM $(46.10 \pm 1.82 \%)$ compared to the DS $(34.19 \pm 1.68)$. For MG, there was no difference in the normality rate between the equipment used (SD: $29.59 \pm 1.78 \%$; PFM: $31.31 \pm 1.48 \%, \mathrm{P}>0.05)$. When compared to the cryoprotectants, DMSO was superior to MG (P $<0.05$ ) in both of the employed equipment.

Table 2. Mean \pm standard error of the percentage of morphologically normal spermatozoa evaluated in post-thaw semen of $C$. macropomum and due to the interaction between the cryoprotectant $\times$ freezing method, and the extender $\times$ freezing method.

\begin{tabular}{llcc}
\hline & & \multicolumn{2}{c}{ Freezing methods } \\
\cline { 3 - 4 } & & Dry shipper & PFM \\
\cline { 3 - 4 } Cryoprotectants & DMSO & $34.19 \pm 168 \mathrm{Ba}$ & Normal (\%) \\
& MG & $29.59 \pm 1.78 \mathrm{Aa}$ & $46.10 \pm 1.82 \mathrm{Aa}$ \\
\multirow{4}{*}{ Extenders } & & $31.31 \pm 1.48 \mathrm{Ab}$ \\
& GLUCOSE & $35.89 \pm 1.70 \mathrm{Aa}$ & $38.16 \pm 1.98 \mathrm{Aa}$ \\
& BTS & $27.90 \pm 1.65 \mathrm{Bb}$ & $39.26 \pm 1.87 \mathrm{Aa}$ \\
\hline
\end{tabular}

$\mathrm{A}, \mathrm{B}$ Capital letters indicate significant differences between the methods of freezing in the same cryoprotectant and extenders $(\mathrm{P}$ $<0.05)$.

${ }^{\mathrm{a}, \mathrm{b}}$ Lower case letters indicate significant differences in the cryoprotectant within the same freezing method $(\mathrm{P}<0.05)$.

When comparing the equipment using the same diluent, the treatments with glucose did not differ $(\mathrm{P}>0.05)(\mathrm{SD}: 35.89 \pm 1.70 \%$; PFM: $38.16 \pm 1.9 \%)$. The percentage of normal cells was already higher $(\mathrm{P}<0.05)$ with the BTS when using PFM $(39.26 \pm$ $1.87 \%)$ compared to DS $(27.90 \pm 1.65 \%)$. However, when comparing diluents in the same equipment, the treatments containing glucose showed a higher percentage of morphologically normal spermatozoa $(\mathrm{P}<0.05)$ when using the DS with no difference between the diluents using PFM $(\mathrm{P}>0.05)$.
Among the observed morphopathology, the bent tail defect (Figure 4A) was found most and was observed to a lesser extent $(\mathrm{P}<0.05)$ in the treatments containing glucose $(51.80 \pm 1.13 \%)$ relative to the BTS $(60.24 \pm 1.29 \%)$ regardless of the cryoprotectants and freezing method. When comparing the equipment used in this study (Figure 4B), PFM provided the lowest percentage ( $\mathrm{P}$ $<0.05)$ of cells with the bent tail defect $(51.77 \pm$ $1.18 \%)$ compared to the DS $(60.27 \pm 1.24 \%)$. The head morphopathology, in turn, were low (0.26 to $2.48 \%$ ) with no differences among cryoprotectants, extenders and freezing methods with each other and in relation to fresh semen. 
Figure 4. Mean \pm standard error of the percentage of sperm with the bent tail defect post-thawing of Colossoma macropomum semen: A) Percentage of bent tail defect of cryopreserved semen using extenders Glucose and Beltsville Thawing Solution thinners (BTS) due to the significant effect of the diluent; B) Percentage of bent tail defect of the cryopreserved semen using the dry shipper and programmed freezing machine equipment according to the interaction with the freezing method. Lowercase letters indicate the difference between the columns within the same parameter $(\mathrm{P}<0.05)$.
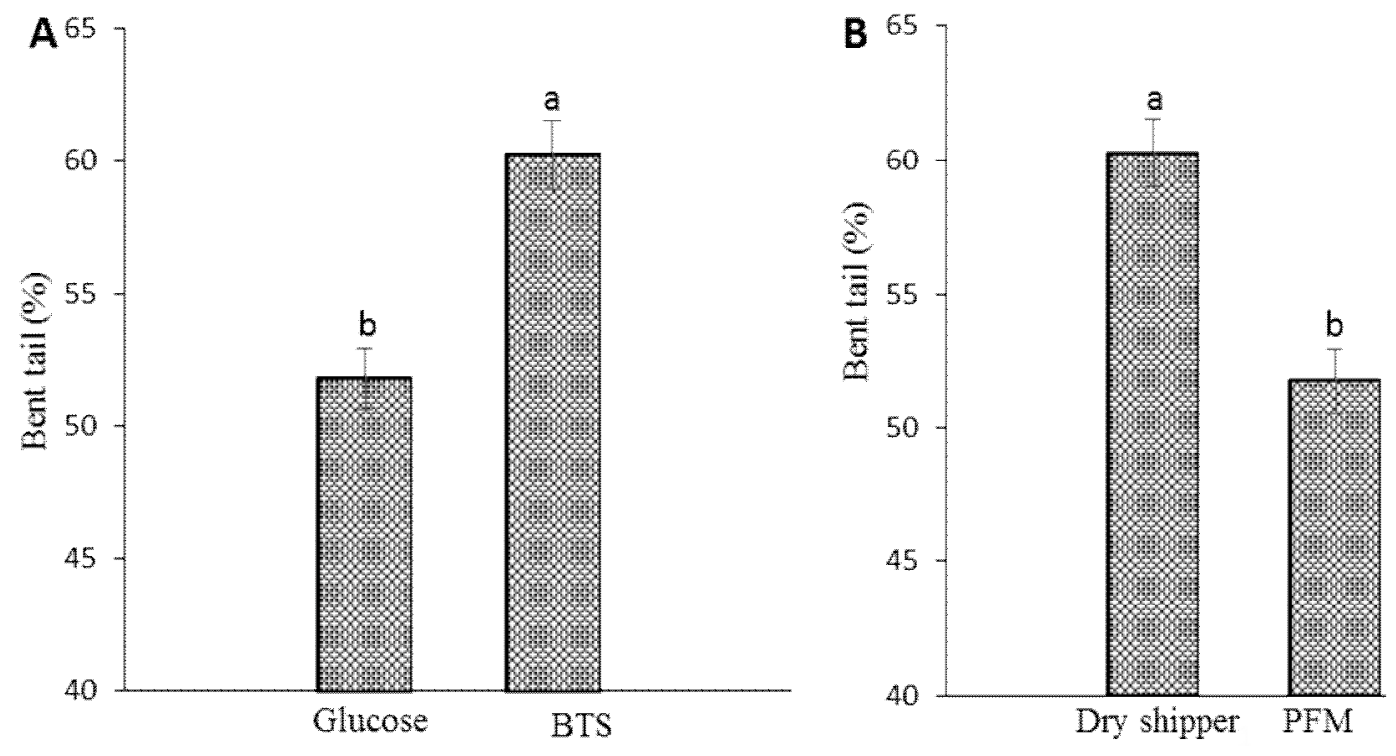

\section{Discussion}

This study aimed to evaluate the interaction between different media freezing and freezing methods and their effect on the kinetic, vitality and morphology of tambaqui sperm using the CASA system. Moreover, this is one of the first cryopreservation studies using a Programmed Freezing Machine for this species with good motility rates, live sperm and normal morphology.

We initially sought to characterize fresh semen because the evaluation of characteristics, such as $\mathrm{pH}$, volume and seminal osmolarity, motility and spermatic concentration, is essential in routine artificial reproduction in any species of fish (SOLIS-MURGAS et al., 2011). In this study, the mean $\mathrm{pH}$ (7.72), volume $(4.31 \mathrm{~mL})$, osmolality (293.96 mOsm), motility $(97.8 \%)$, and sperm concentration $\left(12.98 \mathrm{sptz} \times 10^{9} \mathrm{~mL}^{-1}\right)$ determined for fresh tambaqui semen are within the levels previously recorded for this species (LEITE et al., 2011; VIEIRA et al., 2011).
Other seminal characteristics, such as morphology and sperm vitality, found for tambaqui in this study were approximately $90 \%$ of morphologically normal spermatozoa and 95\% of live sperm, which is in accordance with the data obtained in other studies (KAVAMOTO et al., 1999; VARELA JUNIOR et al., 2012, 2015).

In regard to the results obtained from postthawing semen, it was evident that the decrease in semen quality compared to fresh semen revealed that, as expected, the cryopreservation process causes damage that affects the performance of sperm cells (MARTÍNEZ; PARDO-CARRASCO, 2013).

Among the evaluated parameters, seminal motility is one of the most important factors in the analysis of fish semen (VIVEIROS; GODINHO, 2009). Although recent studies with Characiformes (GODINHO; VIVEIROS, 2011; LOPES et al., 2014) show better motility rates with MG, in this study, the DMSO cryoprotectant provided the best results. 
Indeed, despite its toxicity, DMSO is considered the best cryoprotectant for freshwater fish (SALMITOVANDERLEY et al., 2012) and has provided superior results in various studies with freshwater Brazilian fish such as Brycon insignis (VIVEIROS et al., 2011), Prochilodus lineatus (NASCIMENTO et al., 2012), P. magdalenae (MARTÍNEZ et al., 2012) and C. macropomum (VARELA JUNIOR et al., 2012).

It is also possible noted that the PFM and the DMSO provided better results compared to the DS, which differs from the results found by Carneiro et al. (2012) in a study with tambaqui. It is possible that the best interaction of this cryoprotectant with the cells occurred because the freezing curve used in the PFM is slower than the DS curve. Thus, the choice of the definition of cryoprotectants and the freezing rate simultaneously determine the severity of the physical damage to the sperm by the formation of intracellular ice crystals (MAZUR, 1977). When freezing is conducted at an appropriate rate, there is enough time for the dehydration of the cells, which reduces the intracellular crystal formation and the incidence of cryoinjuries (SANTOS et al., 2013).

Beyond the full motility, the sperm velocities are also related to post-thaw sperm quality. In this study, the highest values for VCL, VSL and VAP were observed in semen cryopreserved with DMSO, which suggests that this is the best cryoprotectant. The VCL is one of the main parameters used in artificial fertilization and has been observed by Viveiros et al. (2010) with cryopreserved $C$. macropomum semen.

Another seminal parameter that should be taken into consideration is the sperm vitality because it also has a direct connection with the fertilizing potential. It was observed in this study that glucose provided a better vitality rate compared to BTS, regardless of the freezing method. This could be because the $5 \%$ Glucose solution can act as an energy substrate, osmotic component and cryoprotectant agent due to its high molecular weight, which contributes to the osmotic balance and works to replace the electrolytes (HOLT, 2000). Thus, this diluent confers better protection to the cell plasma membrane and favors a greater amount of live spermatozoa. Varela Junior et al. (2012) have accomplished fertilization using sperm with zero motility, thus showing that although the sperm may not exhibit motility, its membrane was intact and it retained its genetic material.

Complex solutions, such as BTS, which have $80 \%$ glucose in their composition, have increasingly been used successfully on a large scale for fish semen Characiformes (MILIORINI et al., 2011; SALMITO-VANDERLEY et al., 2012; VARELA JUNIOR et al., 2015). However, the present study showed lower results, which are possibly due to an ineffective association with the cryoprotectants and the freezing methods. In addition, some other components of the BTS (sodium citrate, EDTA, $\mathrm{NaHCO}_{3}, \mathrm{KCl}$, or gentamycin) may have a negative effect on sperm cells during freezing and thawing (NASCIMENTO et al., 2010), and may not be effective for maintaining the integrity of the cell.

Yet, for the vitality parameters, the best rates obtained for DMSO in the PFM and MG in the DS, show an interaction between the cryoprotectant and the freezing velocity. These results indicate that the time the sperm cell remains in contact with the freezing media before the moment of freezing itself and the freezing rate should be appropriate according to the cryoprotectant employed. Furthermore, according to Denvireddy et al. (2002) and depending on the cooling rate, the dehydration process does not effectively occur, which favors the formation of ice within the cell and results in the rupture of the membrane.

Regarding the morphological analysis, the highest percentage of normal sperm was obtained using DMSO, glucose and BTS in PFM. Thus, we see the influence of the equipment used on the postthaw sperm quality; for instance, the programmed freezing machine was more homogeneous and 
favored a gradual drop in temperature and provided the best results compared to the standard equipment (DS) for the seminal freezing of C. macropomum.

The evaluation of the morphology of the sperm in the semen of fish is important to screen for abnormalities that might affect the fertilizing capacity. The greater amount of bent tail among the pathologies observed when BTS and DS were used can be related to ultrastructural changes in sperm due to changes in osmolarity of the medium surrounding them during the cryopreservation process. These alterations are responsible for reducing motility, viability and content of normal spermatozoa (MARQUES, 2001). The presence of this pathology was expected based on studies of Streit Júnior et al. (2009) to cryopreserve Piaractus mesopotamicus semen.

In the present study, the tail morphopathologies were the most frequent, whereas the head occurred in insignificant amounts (0.26 to $2.48 \%$ ), which differed from the results found by Carneiro et al. (2012) who obtained approximately 20\% head abnormalities. It is important to emphasize that while the tail motility defects interfere with fertilization, the head defects most significantly affect fertilization (MILIORINI et al., 2011).

In general, the programmed freezing machine provided better results when compared to the dry shipper, proving to be a less laborious technique and resulted in more homogeneous data regarding other techniques.

The reduction of some values found for the parameters evaluated in this study do not necessarily translate into lower fertilizer capacity; this was verified in the study of Menezes et al. (2008), who registered a $76 \%$ fertilization rate using cryopreserved C. macropomum semen with $20 \%$ motility.

Considering the foregoing, this reinforces the influence of the employment of freezing methods and freezing media and the interaction of these factors on the quality of post-thawed tambaqui semen. The information generated from this research serves as the basis for standardization of cryopreservation protocols and permits its application in aquaculture.

\section{Conclusions}

Within the methodological conditions employed, the use of a $10 \%$ DMSO as the cryoprotectant associated with $5 \%$ Glucose as the diluent by a Programmed Freezing Machine for cryopreservation of C. macropomum semen is recommended because this protocol yielded a better rate of mobile, viable and morphologically normal spermatozoids.

\section{Acknowledgements}

This study was supported by the Universidade Federal do Ceará (UFC) and Laboratório de Biotecnologia da Reprodução de Peixes (LBRP). We acknowledge the Financiadora de Estudos e Projetos (FINEP) for financial support and the Fundação Cearense de Apoio ao Desenvolvimento Científico e Tecnológico (FUNCAP) for granting the scholarship.

\section{References}

BLOM, E. A. One-minute live-dead sperm stain by means of eosin-nigrosin. Fertility and Sterility, Birmingham, v. 1, n. 2, p. $176-177,1950$.

BRASIL. Ministério da Pesca e Aquicultura. Boletim Estatístico da Pesca e Aquicultura. Brasília: MPA, 2011. 60 p. Disponível em: $<$ http://www.mpa.gov.br/files/docs/ Boletim_MPA_2011_pub.pdf $>$. Acesso em: 9 fev. 2015.

CARNEIRO, P. C. F. Tecnologias de produções e armazenamentos de sêmen de peixes. Revista Brasileira de Reprodução Animal, Belo Horizonte, v. 31, n. 3, p. 361-366, 2007.

CARNEIRO, P. C. F.; AZEVEDO, H. C.; SANTOS, J. P.; MARIA, A. N. Cryopreservation of tambaqui (Colossoma macropomum) semen: Extenders, cryoprotectants, dilution ratios and freezing methods. CryoLetters, Lewes, v. 33, n. 5, p. 285-393, 2012. 
DENVIREDDY, R. V.; SWALUND, D. J.; OLIN, T.; VINCENT, W.; TROEDSON, M. H. T.; BISCHOF, J. C.; ROBERTS, K. P. Cryopreservation of equine sperm: optimal cooling rates in the presence and absence of cryoprotective agents determined used differencial scanning calorimetry. Biology of Reproduction, New York, v. 66, n. 1, p. 222-231, 2002.

GODINHO, H. P.; VIVEIROS, A. T. M. Current status of sperm cryopreservation of brazilian characiform fishes. In: TIERSCH, T. R.; GREEN, C. C. Cryopreservation in aquatic species. Los Angeles: World Aquaculture Society, 2011. p. 875-884.

GOULDING, M. A.; CARVALHO, M. L. Life history and management of the tambaqui (Colossoma macropomum, Characidae): an important Ama-zonian foodfish. Revista Brasileira de Zoologia, Curitiba, v. 1, n. 2, p. 107-138, 1982.

HOLT, W. V. Fundamental aspects of sperm cryobiology: the importance of species and individual differences. Theriogenology, New York, v. 53, n. 1, p. 47-58, 2000.

HUNTER, B. J.; ROBERTS, D. C. K. Potential impact of the fat composition of farmed fish on human health. Nutrition Research, Amsterdam, v. 20, n. 7, p. 10471058, 2000.

IRAWAN, H.; VUTHIPHANDCHAI, V.; NIMRAT, S. The effect of extenders, cryoprotectants and cryopreservation methods on common carp (Cyprinus carpio) sperm. Animal Reproduction Science, Amsterdam, v. 122, n. 3-4, p. 236-243, 2010.

KAVAMOTO, E. T.; BARNABE, V. H.; CAMPOS, B. E. S. Anormalidades morfológicas nos espermatozoides do curimbatá, Prochilodus lineatus (Steindachner, 1881) (Osteichthyes, Characiformes, Prochilodontidae). Boletim do Instituto de Pesca, São Paulo, v. 25, n. 2, p. 61-66, 1999.

KOPEIKA, E.; KOPEIKA, J.; ZHANG, T. Cryopreservation of fish sperm. Methods in Molecular Biology, Totowa, v. 17, n. 1, p. 368-203, 2007.

LEITE, L. V.; OLIVEIRA, F. C. E.; NUNES, L. T.; NUNES, J. F.; SALMITO-VANDERLEY, C. S. B. Criopreservação de sêmen de tambaqui com $\mathrm{ACP}^{\circledR}$ adicionado de gema de ovo. Revista Brasileira de Engenharia de Pesca, Maranhão, v. 6, n. 2, p. 23-29, 2011.

LEITE, L. V.; MELO, M. A. P.; OLIVEIRA, F. C. E.; PINHEIRO, J. P. S.; CAMPELLO, C. C.; NUNES, J. F.; SALMITO-VANDERLEY, C. S. B. Determinação da dose inseminante e embriogênese na fertilização artificial de tambaqui (Colossoma macropomum). Arquivo
Brasileiro de Medicina Veterinária e Zootecnia, Belo Horizonte, v. 65, n. 2, p. 421-429, 2013.

LOPES, J. T.; PINHEIRO, J. P. S.; NUNES, L. T.; PINHEIRO, R. R. R.; SOUZA, M. E. M.; ALMEIDA, P. S.; NASCIMENTO, R. V.; CAMPELlO, C. C. C.; SALMITO-VANDERLEY, C. S. B. Avaliação de diferentes crioprotetores e taxas de diluição na criopreservação seminal de Prochilodus brevis. Revista Brasileira de Reprodução Animal, Belo Horizonte, v. 38, n. 3, p. 170-175, 2014.

MARQUES, S. Preservação a curto prazo do sêmen de teleósteos neotropicais de água doce. 2001. Dissertação (Mestrado de Zoologia de Vertebrados) - Pontifícia Universidade Católica de Minas Gerais, Belo Horizonte.

MARTÍNEZ, J. G.; TARAZONA-MORALES, A. M.; PARDO-CARRASCO, S. C. Sperm cryopreservation of freshwater fish bocachico (Prochilodus magdalenae) in DMSO and glucose and its effects on fertilization and hatching efficiency. Animal Reproduction, Belo Horizonte, v. 9, n. 1, p. 19-26, 2012.

MARTÍNEZ, J. G.; PARDO, S. C. Effect of freezing and thawing rates on sperm motility in Bocachico Prochilodus magdalenae (Pisces, Characiformes). Revista MVZ Córdoba, Córdoba, v. 18, n. 1, p. 3295-3303, 2013.

MAZUR, P. The role of intracellular freezing in the death of cells cooled at supra-optimal rates. Cryobiology, Amsterdam, v. 14, n. 3, p. 251-272, 1977.

MENEZES, J. T. B.; QUEIROZ, L. J.; DORIA, C. R. C.; MENEZES JÚNIOR, J. B. Avaliação espermática pósdescongelamento em tambaqui, Colossoma macropomum (Cuvier, 1818). Acta Amazônica, Manaus, v. 38, n. 2, p. 365-368, 2008.

MILIORINI, A. B.; MURGAS, L. D. S.; ROSA, P. V.; OBERLENDER, G.; PEREIRA, G. J. M.; COSTA, D. V. A morphological classification proposal for curimba (Prochilodus lineatus) sperm damages after cryopreservation. Aquaculture Research, Oxford, v. 42, n. 2, p. 177-187, 2011.

NASCIMENTO, A. F.; MARIA, A. N.; PESSOA, N. O.; CARVAlHO, M. A. M.; VIVEIROS, A. T. M. Out-of-season sperm cryopreservation in different media of the Amazonian freshwater fish pirapitinga (Piaractus brachypomus). Animal Reproduction Science, Amsterdam, v. 118, n. 2-4, p. 324-329, 2010.

NASCIMENTO, M. M.; NASCIMENTO, W. S.; CHELLAPA, N. T.; CHELLAPA, S. Biologia reprodutiva do curimatã comum, Prochilodus brevis (Characiformes: Prochilodontidae) no açude Marechal Dutra, Rio Grande do Norte, Brasil. Biota Amazônica, Amapá, v. 2, n. 2, p. 31-43, 2012. 
PAULA, D. A. J.; ANDRADE, E. S.; MURGAS, L. D. S.; FELIZARDO, V. O.; WINALER, E. U.; ZEVIANI, W.; FREITAS, R. T. F. Vitamin E and reduced glutathione in Prochilodus lineatus (curimba) semen cryopreservation (Characiformes: Prochilodontidae). Neotropical Ichthyology. Maringá, v. 10, n. 3, p. 661-665, 2012.

RURANGWA, E.; KIME, D. E.; OLLEVIER, F.; NASH, J. P. The measurement of sperm motility and factors affecting sperm quality in cultured fish. Aquaculture, London, v. 234, n. 1-4, p. 1-28, 2004.

SALMITO-VANDERLEY, C. S. B.; VIEIRA, M. J. A. F.; LEITE, L. V.; OLIVEIRA, F. C. E.; LINHARES, F. R. A.; SAlGUEIRO, C. C. M.; NUNES, J. F. Meios de congelação para conservação de sêmen de peixes da família Characidae. Ciência Animal, Fortaleza, v. 22, n. 1, p. 255-268, 2012.

SANTOS, E. D. A. S.; BARRETO, G. S.; MORAIS, C. A. S. R.; CARVALHO, A. C. M.; SANTOS, J. P.; ARAÚJO, R. V.; MARIA, A. N.; CARNEIRO, P. C. F. Uso do sêmen criopreservado de tambaqui no processo de reprodução artificial. In: SEMINÁRIO DE INICIAÇÃO CIENTÍFICA E PÓS-GRADUAÇÃO DA EMBRAPA TABULEIROS COSTEIROS, 3., 2013, Aracaju. Anais... Brasília: Embrapa, 2013. p. 174-182.

SOLIS-MURGAS, L. D.; FELIZARDO, V. O.; FERREIRA, M. R.; ANDRADE, E. S.; VERAS, G. C. Importância da avaliação dos parâmetros reprodutivos em peixes nativos. Revista Brasileira de Reprodução Animal, Belo Horizonte, v. 35, n. 2, p. 186-191, 2011.

STREIT JÚNIOR, D. P.; OLIVEIRA, A. C.; RIBEIRO, R. P.; SIROL, R. N.; MORAES, G. V.; GALO, J. M.; DIGMAYER, M. Motilidade, vigor e patologias seminal in natura e pós criopreservação de Piaractus mesopotamicus. Boletim do Instituto de Pesca, São Paulo, v. 35, n. 6, p. 159-167, 2009.
VARELA JUNIOR, A. S.; GOULARTE, K. L.; ALVES, J. P.; PEREIRA, F. A.; SILVA, E. F.; CARDOSO, T. F.; JARDIM, R. D.; STREIT JÚNIOR, D. P.; CORCINIC, C. D. Compared. Methods of cryopreservation of Tambaqui semen, Colossoma macropomum. Animal reproduction science, Amsterdam, v. 157, n. 1, p. 71-77, 2015.

VARELA JUNIOR, A. S.; CORCINI, C. D.; GHELLER, S. M. M.; JARDIM, R. D.; LUCIA JUNIOR, T.; STREIT JUNIOR, D. P.; FIGUEIREDO, M. R. C. Use of amides as cryoprotectants in extenders for frozen sperm of tambaqui, Colossoma macropomum. Theriogenology, New York, v. 78, n. 2, p. 244-251, 2012.

VIEIRA, M. J.A. F.; CARVALHO, M. A. M.; SALMITOVANDERLEY, C. S. B.; SALGUEIRO, C. C. M.; VIVEIROS, A. T. M.; MOURA, A. A. A. N.; NUNES, J. F. Características do sêmen de Tambaqui (Colossoma macropomum) em Latitude Equatorial. Archivos de Zootecnia, Córdoba, v. 60, n. 232, p. 1263-1270, 2011.

VIVEIROS, A. T. M.; AMARAL, T. B.; ORFÃO, L. H.; ISAÚ, Z. A.; CANEPPELE, D.; LEAL, M. C. Sperm cryopreservation of tiete tetra Brycon insignis (Characiformes): effects of cryoprotectants, extenders, thawing temperatures and activating agents on motility features. Aquaculture Research, Oxford, v. 42, n. 6, p. 858-865, 2011.

VIVEIROS, A. T. M.; GODINHO, H. P. Sperm quality and cryopreservation of Brazilian freshwater fish species: a review. Fish Physiology and Biochemistry, Amsterdam, v. 35, n. 1, p. 137-150, 2009.

VIVEIROS, A. T. M.; NASCIMENTO, A. F.; ORFÃO, L. H.; ISAÚ, Z. A. Motility and fertility of the subtropical freshwater fish streaked prochilod (Prochilodus lineatus) sperm cryopreserved in powdered coconut water. Theriogenology, New York, v. 74, n. 4, p. 551-556, 2010. 
